\title{
POTENTIAL EFFECTS OF DEMOGRAPHIC TRANSITION ON SUSTAINABLE COMPETITIVENESS
}

\author{
Slavica Manic*, Dragan Azdejkovic \\ Faculty of Economics, University of Belgrade, Belgrade, Serbia
}

\begin{abstract}
In the latest report of the World Economic Forum, it is pointed out that the global competitiveness index does not cover the analysis of the drivers of sustainable competitiveness, and that neglecting them can cause the vulnerability of economies to the negative effects of all future "shocks". Potentially the most problematic ones are demographic questions, especially those concerning changes in the population age structure. Recognizing the importance of demographic trends for "shaping" future competitiveness is the key motive for writing this paper. The main objectives are twofold: a) to review theoretical considerations about the economic consequences of changes in the population age structure; and b) to analyze the characteristics of demographic transition in different regions, as well as its potential effects on the sustainable competitiveness of the economy.
\end{abstract}

Keywords: demographic transition, the age structure of the population, sustainable competitiveness

\section{JEL Classification: J11}

\section{INTRODUCTION}

The influence of population changes on economic growth has been attracting attention of researchers in economics and other social sciences for decades (Maddison, 1995, Bloom et al, 2001, Bloom et al, 2003). As a result of discussions on this issue, three alternative perspectives are differentiated: population growth restricts, promotes or is completely neutral regarding its impact on economic growth, and the character of this effect depends on the level of the development of an economy (all countries being "roughly" divided

\footnotetext{
* Correspondence to: S. Manic, Faculty of Economics, University of Belgrade, Kamenicka 6, 11000 Belgrade, Serbia; e-mail: slavica@ekof.bg.ac.rs
}

into one of the following two categories: developed and developing ones). In addition, it appears that discussions and debates, regardless of the positions they represent, have until recently exclusively been focused on the size and the population growth rates, underestimating the way they are distributed amongst different age groups (Bloom et al, 2001, 1-2; Bloom et al, 2003, xi; Bloom et al, 2011, 3).

Exceptions to the rule, at least when the social and economic aspects of sustainable development are considered, were reports of the Center for Strategic and International Studies (Jackson \& Howe, 2003) trying to measure the "sensitivity" of developed economies to an increase in costs caused by the aging of the population during the current age-structural 
transition. Also, the latest report of the World Economic Forum (WEF, 2011), studying the long-term drivers of productivity (as a crucial element of competitiveness), has once again actualized this problem. The idea of sustainable competitiveness itself is an attempt to integrate sustainability into the concept of the global competitiveness (WEF, 2011, 53), or to determine factors which, in the long run (and with respect to the requirements of sustainable development), may affect productivity, thus also affecting the competitiveness of the national economies in the global milieu. In the area of human capital (as potentially the most sensitive element of national competitiveness), it emphasizes a fact that the demographic changes we are witnessing nowadays can cause a drop in productivity, thereby jeopardizing the long-term national competitiveness. The very dynamics of the demographic transition, as a lengthy time interval during which the trend of high birth and mortality rates evolves towards the low values of these sizes (Dictionary of Economics, 2006, 88), vary across regions and within them. Since the volume and speed of the demographic change are different, their potential effects will consequently manifest in different ways and with varying intensity.

Bearing in mind the necessity of the further reaffirmation of the issues associating demographic changes with sustainable competitiveness, this paper will overview some discussion concerning the implications of the current demographic trends for economic growth; more precisely - we shall try to determine whether there is "evidence" of the impact of changes in the number and age structure of the population on its growth and economic development. On this occasion, we will turn to what is offered by diverse literature on the relationship between the population change and economic development in different regions of the world. In addition, we intend to show the specificity of the demographic transition in Serbia, as well as its potentially problematic effects on the sustainable competitiveness of the economy. The research methodology was adapted to the object and purpose of this paper. For the sake of consistency in the analysis and the comparability of data and/or results, we relied on the available synthesized data of the United Nations' projections of population trends. Calculating the following parameters: a potential support ratio, the share of different age groups and the proportion of the most productive population in the total and working-age population in the case of Serbia, we used the methods of descriptive statistics.

\section{SOME SPECIFIC FEATURES OF THE DEMOGRAPHIC TRANSITION}

Judging by the forecasts of population trends, two quite contradictory demographic phenomena will attract our attention in the coming decades: a further population growth and the rapid aging of the population.

The latest (i.e. the twenty-second so far) report of the United Nations' projections of population trends claimed that the world population had reached the figure of 7 billion in the previous year, and is expected to grow to 9 billion by mid-century (UN, 2011).

This situation is a consequence of the predictable and prolonged impact of an earlier "demographic wave" on the number and age structure of the population. In fact, even when the total fertility rate falls to its replacement level, the population continues to grow as long as those belonging to the aforementioned "wave" are not out of the reproductive age. This process is called the population momentum, and its effects are spread during 50 to 100 years before the age structure has stabilized (Bloom et al, 2001, 18; Bloom et al, 2003, 32). Only owing to the delayed effects of the same are the populations of developing countries supposed to grow by $40 \%$ in this century (Bloom et al, 2001, 19; Bloom et $\mathrm{al}, 2003,32)$; simultaneously, the world's population is supposed to increase by 2 billion people by 2050 (Lutz et al, 2008b, 5). At the end of the last century, even Europe exercised a slow and declining population growth rate thanks to the "wave" and in spite of thirty or more years during which the fertility rate had been below its "replacement" (Coleman, 2006, 4).

On the other hand, in most developed countries, a high level of the old-age dependency ratio $(25 \%$ or more) has already been reached and fertility rates have fallen below their replacement level (which is 2.1 in developed countries and 2.4 in developing ones) and is showing a further decreasing tendency (UN, 2011). 
In the circumstances of the ever-increasing economic interdependence and the intertwining of the economic trends, it means that the creators of the economic policy and other policies are supposed to simultaneously deal with a "pressure" on resources due to the population growth, and a reduced labor supply due to population aging (Lutz et al, 2008b, 3). At the same time, these demographic changes may be of crucial importance in explaining differences in the actual growth rates across countries (Kelley \& Schmidt, 2005, 279).

Having all these in mind, it is essential for our analysis to understand the demographic transition as the key driver directing the evolution of the classic Malthusian population dynamics (driven by the fixed factors of production) to the "mode" of sustainable growth (Galore \& Weil, 2000, 808). It is characterized by the following unsynchronized phenomena: reducing mortality, increasing life expectancy and dramatically declining fertility. The scope, speed and time of these changes are not identical, so that their passing through the stages of demographic changes (the dynamics of the demographic transition) varies across regions and within them.

In fact, some countries have not experienced all the features of the demographic transition yet (countries with high fertility rates, as well as those with 60 or more percent of the population under 30 years of age); others are in its middle phase (when $45-60 \%$ of the population belongs to those younger than thirty); and there are economies characterized by the so-called post-demographic transition - with low fertility rates and the almost completed demographic transition, producing as a result the dominance of the elderly less than $45 \%$ of the population aged under 30 and up to one-quarter of the population older than 60 (Lehr, 2007, 1-26; Poot, 2008, 130-137; Leahy Madsen et al, 2010).

Generally, developing countries are still experiencing a significant increase in their populations. For instance, the African countries have high rates of population growth, Latin America has recently suffered a dramatic decline in the fertility rates, and somewhere between these two extremes are the Middle East and South Asia (Attanasio et al, 2006, 2). Although population growth itself produces a negative effect on the growth of the per-capita income, it can be neutralized by a statistically significant positive effect caused by a growth in the share of the economically active population. In other words, the demographic transition manifests a mechanical effect on the labor supply here: the generations of those able and willing to work are growing up, which - in the circumstances when the labor market is "ready" to absorb them (if properly designed policies and an appropriate institutional environment exist) - can have a positive impact on increasing productivity and income.

Over the last three decades of the twentieth century, the demographic changes in this area have generated the acceleration of the per-capita income from 0.7 to $1.35 \%$ per year (Bloom et al, 2001; Attanasio et al, 2006). This result is modest if we bear in mind that these are the low-income countries; on the other hand, it is (to a certain extent) promising from the standpoint that the demographic transition "in its infancy" generates and explains almost one-third of the growth of underdeveloped countries, and that, over the next five decades, the growth of the per-capita income (on average) will be $0.8 \%$ (Attanasio et al, 2006, 20-21), which means that the "window of opportunity" is still open.

Since capital markets are linked with each other and integrated, the potential effects of the demographic transition on developing countries depend to a large extent on the demographic trends in developed countries as well as the factors mobility (Attanasio et al, 2006, 3). If a synchronized demographic change encourages capital flows to developing countries, their output will grow faster.

The main macroeconomic effects of the completed demographic transition in this area would as well be the following ones: a significant increase in the savings rate, the annual wage increase of approximately $0.4 \%$ over next fifty years, a substantial reduction in interest rates and (which is the most important for our analysis) an increase in an average productivity of 1.5 times during the same time period due to changes in the age structure of the active population, induced by transition in the domain of fertility (Attanasio et al, 2006, 19). 
As for developed countries, the demographic transition has played an important role in the emergence of modern growth by enabling such economies to convert a large part of the gains from the capital accumulation and technological progress into the growth of the percapita income (Galore \& Weil, 1999, 151; Galore, 2010, 1).

Appropriate and timely decisions in the field of the economic policy were the fundamental prerequisite to exploit the opportunities offered by the demographic circumstances. Several variables affected the ability of some economies to do so. They include: the health policy, family planning, the educational policy and the economic policy measures improving the labor market's flexibility and openness, and promoting savings. They all had (and still have) a direct and indirect (collateral - Bloom et al, 2001) influence on the pace of the demographic transition, economic growth and development.

The countries experiencing the effects of a rapid demographic transition (during the 1960's and the 1970 's) were exactly those achieving the significant rates of economic growth; economists refer to this phenomenon as the "demographic dividend". Thus, for example in the case of East Asia, one-third of the achieved results are attributed to the exploitation of favorable demographic circumstances (Bloom et al, 2000, 282).

However, the demographic dividend is not an inevitable thing; quite the contrary - it must be "earned". Hence, it is no wonder that such one-time (time-limited) "demographic gift" (Golin \& Marini, $2005,1)$ is considered to be economically meaningful if there is a "proper investment in human and physical capital and if job opportunities for young people are created" (World Bank, 2003, 36).

In fact, if an increase in the working-age population is not accompanied by certain circumstances of their employment, it will consequently cause rising unemployment. Therefore, an emphasis on applied and properly designed policies is important since the acquiring of the "demographic dividend" is not possible by a sort of default. In other words, the demographic transition leading to the "domination" of the workingage population group, represents an opportunity and a chance for a country to eventually materialize such an advantage (in the form of higher productivity and growth rates). This is what Japan has done, having experienced the so-called "population bonus" - the high rates of growth owing to an increased share of the working-age population (Shirakawa, 2011).

However, the demographic bonus in the twentieth century appears to have expired (at least when developed economies are considered) (Coleman, 2006). Specifically, according to forecasts (UN, 2011), by the middle of this century, developed countries will have experienced an increase in their populations over the age of 60 by more than $50 \%$ (or $2.4 \%$ per annum). The number of elderly people in this area has already surpassed the number of children (persons under the age of 15), and its share in the total population, from the current $22 \%$, will have reached $32 \%$ by the year 2050. The proportion of the working-age population, as an important factor showing a potential for economic growth, was slightly falling in the time period 19501970 only to increase to a certain extent by the year 2005 (when it reached 63\%), and then again to manifest a tendency to decrease (according to the projections for the year 2050, it will have amounted to 51.5\%). In other words, the average annual rate of the change in the group of developed countries will have been negative $(-0.31 \%)$ over the next four decades, primarily due to the extremely unfavorable tendencies in Europe (where an annual reduction of the working population of $0.61 \%$ is expected, resulting in the future share of this group in the overall population of about $50 \%$ ). Although the literature in the field of demography and economics did not reach a consensus on the definition of the population bonus (saying that this is either a time period when the proportion of the working-age population is over $65 \%$ or believing that an increase in percentage is the only thing that matters - Shirakawa, 2011, 4), there is no doubt that, in this situation, researchers in various fields will agree that developed countries are on the threshold of or have greatly stepped into the era of the population "bonus" (when the current structure of the population represents rather a burden and an obstacle to a further prosperity).

In principle, developed countries have come to an end of their demographic transition. This means that, in some of them (such as Italy, Spain, Japan, Korea, Singapore 
and Taiwan), the changes are already evident in the form of the workforce reductions and the accelerated aging of the population, while in others, they will have been manifested in no later than ten to twenty years (Bloom et al, 2003; Lutz et al, 2008b). This phenomenon raises new challenges in the sphere of distribution (in terms of transferring income from the active workforce to those who are not), leading to a lower productivity growth, less flexibility in the labor market, the increased costs of health insurance, nursing and health care (Heller, 2003; Poot, 2008; Shirakawa, 2011).

To determine whether there is a pattern according to which the number of a population and a population structure affect its economic growth, Bloom and others (2011) compared the demographic trends in the time period 1960-2005 with those projected by mid-century (exploring what economic growth could be achieved if the demographic changes are like today's projections say). Their calculation determined that in the circumstances predicted by the demographic scenario for the future, more than one-half of the countries would experience a slower growth, and, speaking of the OECD countries, their past (in demographic terms) as particularly good (Bloom et al, 2011, 19). In other words, the time period when developed economies have a high proportion of the working-age population and an appropriate demographic composition (i.e. the predominant share of the most productive group those between 30 and 49 years of age - Prskawetz, 2007) has ended; now, they are awaiting entirely different demographic trends with unfavorable economic consequences.

All the above-mentioned calculations are related to the accounting effects and neglect the following changes in behavior that may be initiated by the changes in the age structure: a) due to an increased life expectancy, the working period is extended: the average age for retirement at the level of European Union in the time period 2001-2008 increased from 59.1 to 61.4 years of age (Bloom et al, 2011, 10), and there are suggestions that it should be increased to 72-75 years (Coleman, 2006, 27); this transferred individuals from the "dependent" to those economically active (changing both the numerator and the denominator of the dependence ratio) simultaneously preventing the slowing-down or reduction of the achieved living standard; $b$ ) an increased life span induced an increase in savings over the working period; c) the labor participation is increased (owing to the greater participation of women); d) investments in human capital are changing - a forecast made by Becker (Becker \& Luis, 1973) saying that parents will have fewer but better-educated children turns out to be accurate, although it remains unclear whether a smaller group of more productive people (through increasing the average income and reducing the tax burden) can compensate for a larger group of less productive members of the society; e) the employment of the older population is consequently increasing.

Bearing in mind the already mentioned possibilities of adjustment, the cumulative effect of the changes (in the age structure of the population in developed countries) on their productivity, competitiveness and economic growth appears to theoretically be ambiguous (Poot, 2008; Bloom et al, 2011): the accounting effects are negative (Jones, 2005); however, they might partially be offset under the influence of the behavioral factors.

\section{MITIGATION OF THE NEGATIVE CONSEQUENCES OF THE AGE-STRUCTURAL TRANSITION IN EUROPE: POSSIBLE (NON-) DEMOGRAPHIC SOLUTIONS}

At the beginning of this century, analysts projected that, because of the long-lasting decline in the fertility rates, the population of Europe would be decreasing by $6 \%$ over the next 25 years, and that, by the mid-XXI century, the region's share in the world population would manifest a tendency of a constant decline (UN, 2001). Nowadays, $10.6 \%$ of the world population lives in Europe; due to the expectations that the average annual population growth rate over the next forty years will be negative $(-0.24 \%)$, it is predicted that this area will be inhabited by between $6.1 \%$ and $7.8 \%$ of the world population in the year 2050 (UN, 2011). A continuous fall in the fertility rates will keep on inducing the aging of the population; in the long run, when the birth rates stabilize, a constant reduction in the mortality rates will become the only one cause of the aging (Coleman, 2006, 19). 
A concern about population aging has initiated a series of discussions on this subject, and special attention has been paid to the future trends of the "potential support" ratio (comparing the number of the nominally active people (usually those aged 15 to 64) to the number of elderly people (those over 65 years of age). In most European countries, the above-mentioned ratio was nearly 4 at the beginning of this century, and according to the expectations and forecasts of the situation by mid-century, it will have been about 2 at the European level and 1.4 in Southern Europe (UN, 2011).

In this decade, the number of the people in the most productive working age will reach its peak, only to be followed by yet another fall. Also, unlike the midtwentieth century, when the proportion of young people in European countries amounted to $27 \%$ and those older than 60 to $12 \%$, by the middle of this century, these shares are expected to change dramatically and reach $16 \%$ and $33 \%$, respectively, whereas the average age of the Europeans will have increased from 38 years of age in 2000 to 49 years of age in 2050 (UN, 2011).

The European countries are therefore faced with a problem that the growing number of the elderly relies on the reduced number of the working age population. The regions of Eastern and Southern Europe are in a particularly difficult situation; under the circumstances of low fertility and a considerable emigration, they are undergoing a rapid decrease in the population (in both absolute and relative terms), which will halve their populations during this century (Lutz et al, 2008b, 8).

These trends are very problematic, especially if the fact that some countries in the region have missed an opportunity to take advantage of their previous, somewhat atypical, demographic trends is taken into account. Specifically, compared with the other parts of world, in the middle of the last century, this region had a high proportion of the working age population; however, they failed to benefit from that (Bloom et al, 2003, 67). Also, the proportion of the elderly in Eastern Europe was lower (only 12.9\%) compared to other Europe's regions; apart from Serbia and Albania, at the end of the last century, the percentage of the elderly population in Russia was the lowest in Europe (Coleman, 2006, 9). This was obviously a time when several countries still had an "open window" (Golin
\& Marini, 2005, 3) on the path of their demographic transition. By mid-century, the share of the elderly in Eastern Europe will have increased to 26\%, and in Southern Europe, there will have been even 33\% of the population older than 65 (Coleman, 2006, 19). The difficulties regarding the then efficiency and competitiveness will further be complicated due to the aforementioned aging, and as a consequence of reducing the working age population (especially the younger segment of it).

Bearing in mind the disadvantages of the current demographic situation, it is logical to examine what possibilities of mitigating their (certainly negative) pulses to economic growth developed countries have at their disposal. Roughly speaking, the solutions can be divided into the demographic and non-demographic ones (Coleman, 2006).

The choice of the demographic solutions is of a moderate character - an increase in fertility and an "enhanced" migration are essential for an increase in the potential support ratio. Specifically, for merely maintaining the current level of the ratio, the total fertility rate in Europe would have to rise to 3.5, which is a "mission" impossible. Can a migration of younger people compensate for the population deficit created by the low birth rates?

Although the general benefits of the migration of the skilled labor force are undeniable, the effects of these immigration trends seem not to be considerable - for example, if we want to preserve the current level of the potential support ratio, approximately 25 million people per year would have to migrate to Europe (Coleman, 2006, 22). That is why the idea that it would constitute a kind of an economic "salvation" for Europe is fully rejected (Coleman \& Rowthorn, 2004, 699). In addition, in some parts of South-Eastern Europe, the situation is even more complicated - being developed at a much lower level, they are not considered to be an attractive area for immigration.

So, it seems that there are no demographic solutions to population aging. Therefore, it is necessary to resort to non-demographic answers (solutions) related to the improvements in the education sphere, adjustments in the labor markets, the pension systems and the age of retirement. 
Increased investments in the education of the workingage population are an important determinant with an exclusively positive effect on economic growth (Lutz et al, 2008a). Assuming the "scenario" of global education, i.e. future trends in enrollment (transition to a higher level of education) in each country follow the overall historical trajectory of global trends (Lutz et al, 2008b, 15), the educational profile of the workforce will undoubtedly be constantly improving.

If, however, the labor inputs continue to decline owing to technological changes, this combination of less numerous but better-educated workers might have a stimulating effect on an increase in labor productivity - exactly what the European countries are in need of (Lutz et al, 2008b, 22). However, it is uncertain whether the positive effects of a higher educational attainment will be able to compensate for the negative ones created by the above-mentioned reduction in the workforce.

In addition, less developed countries are generally faced with the problems of the unreformed labor markets and pension systems, and those countries that are (from the demographic point of view) in the worst position at the same time have the largest institutional problems (Jackson \& Howe, 2003). So, given the fact that population aging is not treated as a demographic problem per se (Bloom et al, 2011, 29), but rather as a function of rigid and outdated institutions and policies, the combination of "answers" for the proper "handling" of these changes is considered to be necessary and indispensable. This could involve the following actions (Coleman, 2006, 25-28):

- Improving the ratio of "real" support, i.e. increasing the proportion of the current labor force (through an increased participation of women in the workforce, shortening studies, finding the first job earlier);

- The modification of the mandatory and further development of voluntary pension insurance;

- Stimulating capital investments in order to improve productivity (and thus competitiveness and economic growth); the productivity growth required to "cover" a problem that occurs due to population aging (increasing the category of the "dependent") would have to be at least $0.5 \%$ per year until 2020.

\section{THE DEMO-ECONOMIC TRANSITION OF SERBIA}

What are the trends in the population changes observed in Serbia? Are they just the reflection of the same tendencies manifested in the region of Southeast Europe? Has the situation deteriorated from the last decade of the previous century since the general economic conditions were not favorable for the demographic and demo-economic evolution?

Given the fact that the demographic indicators in Serbia are rather contradictory, it seems that in this case, the reasoning which is the as the one in the region of Southeast Europe applies. On the one hand, in fact, some parameters from the last decade of the previous century indicate that there was room to take advantage of the relatively favorable demographic situation of the time. Thus, for example, the proportion of the workingage population to the total population was $67.2 \%$, whereas the share of the elderly was only $9.6 \%$ (UN, 2011). Also, when (using the available data of the UN) we calculated the proportion of the most productive group in the total population as well as the working-age population and compared it with the same indicators in the other European regions, the results were similar and relatively promising. The share of those aged3049 in the total population in the last decade of the previous century amounted to $27.5 \%$ in Serbia, while its proportion in the working-age population was $41 \%$; these sizes correspond to those achieved in the region of Northern Europe. However, when some other indicators were calculated, the situation seemed to be an extremely unfavorable one - as if the demographic opportunities had not existed at all. Thus, for example, the share of children and young people up to 30 years of age in the total population in Serbia stood at $44.75 \%$, while the share of the population above 60 years of age accounted for $15.33 \%$. Since there was less than $45 \%$ of the population aged under 30 , and nearly a quarter of those 60 plus and older, it reflected the socalled mature age structure, however unfavorable for economic growth and development.

The situation in Serbia is even more serious since the last decade of the twentieth century represented the embodiment of the simultaneous performing of two types of transition, and it eventually turned out that 
they had not been proceeding independently of each other: the economic transition, which began at that time, and the demographic transition - which had lasted for decades before that time.

In the mid-1950's, Serbia recorded the total fertility rate of around 2.1, providing a simple renewal of the population; the rate lowered to 1.74 in the 1990's (UN, 2011), with a decreasing trend expected to be lasting until the second half of this century. The reducing of the fertility rates was, among other things, the consequence of the economic transition, namely: a dramatic reduction in the living standard, increased poverty, greater insecurity in terms of job and income, the emigration of the young population and the like.

Although the demographic transition has the characteristics of regional variations (differentiating the areas of under versus over population growth), Serbia as a whole is also faced with a depopulation process. According to the forecasts, Bosnia and Herzegovina, Bulgaria, Croatia, Serbia, Russia, Romania belong to the group of 49 countries whose population will be shrinking in the mid-century by at least ten percent (due to a prolonged decline in fertility below its replacement level) (UN, 2011).

Since the year 2000, the changes in the age structure have been moving in the direction of an absolute decrease and a relative one in the share of young people, simultaneously being increased in the share of those belonging to the older generation, which are the features of the countries undergoing the postdemographic transition (Lehr, 2007; Poot, 2008). The total dependency ratio is increasing and the effects of aging on the further economic and demographic evolution are expected to manifest particularly in this decade. Specifically, the contingent of the working-age population (as the main source of the active population) consists of fewer generations of those born in the time period of the economic transition, and the problem emphasizes the decline of their participation in the labor market (their later entering the market) as a result of an extended time period of their schooling (which is a forced response to the reduced opportunities for finding a job immediately after graduation).

Hence, it is no surprise that the potential support ratio, which was at the level of 4.87 (and above the
European average) at the end of the last century, will begin to fall rapidly over the next ten years and is expected to reach 2.43 by the middle of this century. Unlike the developed countries of North and Western Europe, which will maintain a relatively constant share of their populations aged 30-49 in the workingage group, Serbia will be suffering a decline in this size, too. If about half a million people who emigrated from the country during the time period 1995-2005 (UN, 2011) are taken into account, the situation seems to be far more onerous. Specifically, the migratory movements (the more rapid emigration) caused not only the current decline in the population but also the long-term demographic consequences (in terms of a loss of potential, future offspring). They also imposed the structural changes, since the emigration of highly educated young people produced the negative consequences for productivity, economic growth and development.

Therefore, the analyzed demographic solutions for solving the problems produced by the demo-economic evolution in this area are completely unusable. Serbia cannot increase the potential support ratio owing to migration since it is not an attractive area for immigration. Although only the fertility rate can substantially change the composition of the population groups, this solution is also irrelevant for Serbia because the population deficit caused by the low birth rates cannot be compensated for in the circumstances where the rate is becoming even lower.

The changed structure of the population is no longer a strictly demographic problem because the time of the economic transition (with the poor economic conditions and large gaps in human resources management) has only made (the already negative) trends worse, leaving its mark in the disorder of the demographic transition. Since the problem goes beyond the scope of demography, the non-demographic solutions to ADRESS it are the only thing available in Serbia at the moment.

\section{CONCLUSION}

The study of the impact of population changes on a country's economic growth and its development is 
becoming more attractive for researchers not only because of the objective actualization of the issue in the decades to come but also owing to an increased interest expressed by institutions bearing a decisive influence on the deepening of the analysis in the domain of competitiveness.

In the next few decades, the world will be faced with two opposite trends: a further increase in the population and rapid population aging. The high fertility rates in the group of underdeveloped countries produce negative effects on their per capita income. On the other hand, the growth of the working-age and economically active population may produce an increase in their labor productivity and consequently induce income growth. However, only in simple economic models do some types of the economic policy enable the exploitation of the advantages of the current age structure in developing countries and the acquisition of the demographic dividend. In real circumstances, as we have seen, the effects of the demographic changes in this area are not considerable: they are supposed to generate annual growth in the per-capita income of $0.8 \%$, but it is not such a kind of acceleration that would bring a fundamental change in the status of underdeveloped countries.

Developed economies are being faced with the so-called age-structural transition. In fact, the demographic transition has left them a legacy in the form of an aging population in XXI century. Although an increase in the share of this (from economy's standpoint) unproductive segment of the population may produce certain negative effects and does inhibit economic growth, the consequences need not be fatal, under a rigorous assumption that it is feasible and possible to perform simultaneous behavioral adjustments in the form of an extended working period, greater savings and increased investments in human capital.

In demographic terms, Serbia shares the fate of developed countries regarding the issues of the declining fertility and the increasing proportion of the elderly. However, the Serbian situation is more serious due to the disturbances in the demographic transition caused by the economic transition. Like the other European countries, Serbia needs investments in human capital, so that an improvement in the education and the achievements of the working population may induce an increase in its productivity, thus (at least partially) compensating for the negative consequences of both the population decline and its aging. Therefore, an analysis of possible non-demographic solutions appropriate to the demographic transition in Serbia could be the subject matter of a subsequent research; it may as well produce positive developments in the field of the sustainable competitiveness of its economy.

\section{ACKNOWLEDGEMENTS}

The research in this paper was conducted within Project No. 179065 , funded by the Ministry of Science of the Republic of Serbia.

\section{REFERENCES}

Attanasio, O., Kitao, S., \& Violante, G. L. (2006). Quantifying the Effects of the Demographic Transition in Developing Economies. Advances in Macroeconomics, 6(1), 1-44.

Becker, G. S., \& Lewis, H. G. (1973). On the interaction between the quantity and quality of children. Journal of Political Economy, 81(2), 279-288.

Bloom, D., Canning, D., \& Malaney, P. (2000). Population Dynamics and Economic Growth in Asia. Population and Development Review, Supplement to Volume 26, 257-290.

Bloom, D., Canning, D., \& Sevilla J. (2001). Economic Growth and the Demographic Transition. NBER Working Paper 8685. Retrieved January 30, 2012, from http://www.nber.org/ papers/w8685

Bloom, D., Canning, D., \& Sevilla J. (2003). The Demographic Dividend, A New Perspective on the Economic Consequences of Population Change. Pittsburgh: Population Matters, A Rand Program of Policy-Relevant Research Communication

Bloom, D., Canning, D., \& Fink, G. (2011). Implications of Population Aging For Economics Growth. Program on the Global Demography of Aging. PGDA Working Paper, 64. Retrieved January 30, 2012, from http://www.hsph.harvard. edu/pgda/working.htm

Coleman, D. A., \& Rowthorn, R. (2004). The economic effects of immigration into the United Kingdom. Population and Development Review, 30(4), 579-624. 
Coleman, D. (2006). Europe's Demographic Future: Determinants, Dimensions and Challenges. Retrieved January 30, 2012, from http://www.spsw.ox.ac.uk/fileadmin/ documents/pdf/WP32_Europe_s_Demographic_Future.pdf

Ekonomski rečnik. (2006). Beograd: Ekonomski fakultet.

Heller, P. (2003). Who Will Pay? Coping with Aging Societies, Climate Change and Other Long-Term Fiscal Challenges. Washington: International Monetary Fund.

Galor, O., \& Weil, D. (1999). From Malthusian Stagnation to Modern Growth. American Economic Review, Papers and Proceedings, 89(2), 150-154.

Galor, O., \& Weil, D. (2000). Population, Technology and Growth: From Malthusian Stagnation to the Demographic Transition and Beyond. American Economic Review, 90(4), 806-828.

Galor, O. (2010). The Demographic Transition: Causes and Consequences. Retrieved January 30, 2012, from http://www. brown.edu/Departments/Economics/papers/2010/2010-12_ paper.pdf

Golini, A., \& Marini, C. (2005). Demographic changes as factor of national development and international competitiveness. Retrieved January 30, 2012, from http://iussp2005.princeton. edu/download.aspx?submissionID $=51063$

Jackson, R., \& Howe, N. (2003). The 2003 Aging Vulnerability Index. Washington, D.C: Center for Strategic and International Studies and Watson Wyatt Worldwide. Retrieved January 30, 2012, from http://csis.org/files/media/csis/pubs/aging_index. pdf

Jones, B. F. (2005). Age and great invention. NBER Working Paper 11359, Cambridge: National Bureau of Economic Research. Retrieved January 30, 2012, from http://www.nber. org/papers/w11359.pdf

Kelley, A. C., \& Schmidt, R. M. (2005). Evolution of recent economic-demographic modeling: a synthesis. Journal of Population Economics, 18(2), 275-300.

Leahy Madsen, E., Daumerie, B., \& Hardee, K. (2010). The effects of age structure on development, Policy and Issue Brief. Washington, DC: Population Action International. Retrieved January 30, 2012, from http://www.populationaction.org/ oldmedia/SOTC_PIB.pdf
Lehr, C. S. (2007). Evidence on Demographic Transition. Retrieved January 30, 2012, from http://www.people.vcu. edu/ cascotese/Publications/Demographic\%20Transition. pdf

Lutz, W., Sanderson, W., \& Scherbov, S. (2008a). The Coming Acceleration of Global Population Ageing. Nature, 451, 716719 .

Lutz, W., Sanderson, W., Scherbov, S., \& Samir, K.C. (2008b). Demographic and Human-Capital Trends in Eastern Europe and Sub-Saharian Africa. Washington, D.C: Migration Policy Institute.

Maddison, A. (1995). Monitoring the World Economy: 1820-1992. Paris: OECD Development Centre.

Poot, J. (2008). Demographic change and regional competitiveness. Journal of Foresight and Innovation Policy, 4(1/ 2), 129-145.

Prskawetz, A., \& Lindh, T. (Eds.). (2007). The Relationship Between Demographic Change and Economic Growth in the EU, Research Report 32, Vienna Institute of Demography, Retrieved January 30, 2012, from http://www.oeaw.ac.at/vid/ download/FB32.pdf

Shirakawa, M. (2011). The Transition from High Growth to Stable Growth: Japan's Experience and Implications for Emerging Economies. Remarks at he Bank of Finland 200th Anniversary Conference, Retrieved January 30, 2012, from http://www.bis.org/review/r110510a.pdf

United Nations. (2001). World Population Prospects: The 2000 Revision. Retrieved January 30, 2012, from http://www. un.org/esa/population/publications/wpp2000/chapter5.pdf

United Nations. (2011). World Population Prospects: The 2010 Revision. Retrieved January 30, 2012, from http://esa.un.org/ unpd/wpp/Documentation/publications.htm

World Bank. (2003). World Development Indicators. Washington DC, Retrieved January 30, 2012, from http://www.worldbank. org/data/wdi2003/people.pdf

World Economic Forum. (2011). The Global Competitiveness Report 2011-2012. Retrieved December 2, 2011, from http:// reports.weforum.org/global-competitiveness-2011-2012/\#=

Received 14 June 2012, after one revision, accepted for publication 9 July 2012 
Slavica Manic is an Assistant Professor at the Faculty of Economics, University of Belgrade, Serbia. She obtained her Ph.D. degree from the Faculty of Economics, University of Belgrade. The areas of her scientific research: economic methodology, economic theory, heterodox approaches, competitiveness policy.

Dragan Azdejkovic is an Assistant at the Faculty of Economics, University of Belgrade, Serbia. He received his Ph.D. degree from the Faculty of Economics, University of Belgrade. The areas of his scientific research: decision theory, game theory, econometrics, fuzzy systems. 


\title{
POTENCIJALNI EFEKTI DEMOGRAFSKE TRANZICIJE NA ODRŽIVU KONKURENTNOST
}

\author{
Slavica Manić, Dragan Azdejković* \\ Ekonomski fakultet Univerziteta u Beogradu
}

\begin{abstract}
U najnovijem izveštaju Svetskog ekonomskog foruma ustanovljeno je da indeks globalne konkurentnosti ne pokriva analizu pokretača održive konkurentnosti, a zanemarivanje istih može prouzrokovati preosetlijvost privreda na negativne posledice svih budućih "šokova". U potencijalno najproblematičnija uključena su demografska pitanja, pogotovo ono koje tangira promene u starosnoj strukturi stanovništva. Prepoznavanje važnosti demografskih tokova za "oblikovanje" konkurentnosti u narednom periodu predstavlja ključni motiv za pisanje ovog rada. Osnovni ciljevi su sledeći: a) da se prikažu teorijska saznanja o ekonomskim konsekvencama promena u starosnoj strukturi stanovništva; b) da se analiziraju osobenosti demografske tranzicije u različitim regionima i potencijalni efekti iste na održivu konkurentnost privrede.
\end{abstract}

Ključne reči: demografska tranzicija, starosna struktura stanovništva, od rživa konkurentnost

\section{JEL Classification: J11}

\section{UVOD}

Uticaj populacionih promena na ekonomski rast već decenijama zaokuplja pažnju literature iz oblasti ekonomije i drugih društvenih nauka (Maddison, 1995; Bloom et al, 2001; Bloom et al, 2003). U raspravama povodom ovog pitanja izdvojila su se tri alternativna gledišta: da rast stanovništva ograničava, podstiče ili je potpuno neutralan po pitanju uticaja na ekonomski rast, te da karakter ovog uticaja zavisi od dostignutog nivoa razvijenosti privrede (pri čemu se vrši "gruba" podela na dve kategorije zemalja: razvijene i zemlje $u$ razvoju). Pored toga, čini se da su diskusije i debate,

\footnotetext{
* Korespondencija: S. Manić, Ekonomski fakultet Univerziteta u Beogradu, Kamenička 6, 11000 Beograd, Srbija; e-mail: slavica@ekof.bg.ac.rs
}

nezavisno od pozicije koju zastupaju, sve do nedavno bile isključivo usmerene na veličinu i stope rasta stanovništva, potcenjujući značaj načina na koji je ono raspoređeno po različitim starosnim grupama (Bloom et al, 2001, 1-2; Bloom et al, 2003, xi; Bloom i et al, 2011, 3).

Izuzetke od pravila, bar kad je reč o društvenim i ekonomskim aspektima koncepta održivog razvoja, predstavljaju izveštaji Centra za strateške i međunarodne studije (Jackson \& Howe, 2003), koji pokušavaju da mere "osetliivost" razvijenih privreda na porast troškova prouzrokovanih starenjem populacije u uslovima aktuelne starosno-strukturne tranzicije. A onda se pojavio najnoviji izveštaj Svetskog ekonomskog foruma (World Economic Forum, 2011), koji u kontekstu proučavanja dugoročnih pokretača produktivnosti (kao 
ključnog elementa konkurentnosti) ponovo aktuelizuje ovaj problem. Sama ideja održive konkurentosti predstavlja pokušaj da se izvrši integrisanje održivosti u koncept globalne konkurentnosti (WEF, 2011, str. 53), odnosno, da se ustanovi koji su to faktori koji na dugi rok (a uz poštovanje zahteva održivog razvoja) mogu uticati na produktivnost, a time i na konkurentnost nacionalnih privreda $\mathrm{u}$ globalnom miljeu. $\mathrm{U}$ domenu ljudskog kapitala (kao potencijalno najosetljivije oblasti za nacionalnu konkurentnost), naglašava se da upravo demografske promene čiji smo svedoci u današnje vreme mogu prouzrokovati pad produktivnosti čime se dugoročno ugrožava nacionalna konkurentnost. Sama dinamika demografske tranzicije, kao podužeg vremenskog intervala tokom kojeg trend visokih stopa nataliteta i mortaliteta evoluira ka niskim vrednostima ovih veličina (Ekonomski rečnik, 2006, 88), se razlikuje po regionima i unutar njih. A pošto su obim i brzina demografskih promena različiti, onda će se i njihovi potencijalni efekti ispoljavati na drugačije načine i sa promenljivim intenzitetom.

Imajući u vidu neophodnost dalje reafirmacije pitanja koja dovode $u$ vezu demografske promene i održivu konkurentnost, u radu ćemo datipregled nekih diskusija o mogućim posledicama aktuelnih demografskih trendova na ekonomski rast, preciznije - pokušaćemo da ustanovimo da li postoje "dokazi" o uticaju promena u broju i starosnoj strukturi stanovništva na rast i razvoj privreda. Tim povodom ćemo se osvrnuti na ono što je raznolika literatura ponudila o odnosu populacionih promena i ekonomskog razvoja $\mathrm{u}$ različitim regionima sveta. Pored toga, namera nam je da ukažemo na specifičnost demografske tranzicije $u$ Srbiji i potencijalno problematične efekte iste na od rživu konkurentnost privrede. Metodologija istraživanja je prilagođena predmetu i cilju ovog rada. Radi konzistentnosti $u$ analizi i uporedivosti podataka i/ili rezultata, oslonili smo se na raspoložive sintetizovane podatke Ujedinjenih Nacija o projekcijama u kretanju stanovništva. Pri izračunavanjima sledećih pokazatelja: racia potencijalne podrške, udela različitih starosnih grupa i najproduktivnije populacije $u$ ukupnom $i$ radno-sposobnom stanovništvu na primeru Srbije, koristili smo metode deskriptivne statistike.

\section{NEKE SPECIFIČNOSTI DEMOGRAFSKE TRANZICIJE}

Sudeći po prognozama o kretanju stanovništva, $\mathrm{u}$ narednim decenijama dva, sasvim oprečna, demografska fenomena zaokupljaće našu pažnju: dalji porast broja stanovnika i ubrzano starenje populacije.

U najnovijem (inače, dvadeset drugom dosad) izveštaju Ujedinjenih Nacija o projekcijama kretanja populacije, ustanovljeno je da je broj stanovnika u prethodnoj godini dostigao broj od 7 milijardi, a do sredine ovog veka očekuje se da svetska populacija naraste do 9 milijardi ljudi (UN, 2011).

Ovakva situacija je posledica predvidivog i produženog uticaja ranijeg "demografskog talasa" na broj i starosnu strukturu stanovništva. Naime, čak i kad ukupna stopa fertiliteta padne na nivo "proste reprodukcije", stanovništvo nastavlja da raste sve dok oni koji pripadaju pomenutom "talasu" ne izađu iz reproduktivnog doba. Ovaj proces se naziva populacioni momentum, a njegovi efekti se prostiru u periodu od 50 do 100 godina pre no što se starosna struktura stanovništva ustali (Bloom et al, 2001, 18; Bloom et al, 2003, 32). Samo usled prolongiranog dejstva istog, očekuje se da stanovništvo zemalja u razvoju u ovom veku naraste za $40 \%$ (Bloom et al, 2001, 19; Bloom et al, 2003, 32), a da se svetska populacija do 2050. godine uveća za 2 milijarde ljudi (Lutz et al, 2008b, 5). Zahvaljujući ovom "talasu", čak se i u Evropi krajem prošlog veka ostvarivao spor i opadajući nivo rasta stanovništva uprkos trideset ili više godina tokom kojih je stopa fertiliteta bila ispod nivoa "zamene" (Coleman, 2006, 4).

S druge strane, $u$ većini razvijenih zemalja, već je dostignut visok nivo racia zavisnosti starijeg stanovništva ( $25 \%$ i više), a stope fertiliteta su pale ispod nivoa zamene (koji iznosi 2,1 u razvijenim zemljama, a 2,4 u nerazvijenim zemljama) $\mathrm{i}$ ispoljavaju tendenciju daljeg smanjivanja (UN, 2011).

U uslovima nikad veće ekonomske međuzavisnosti i isprepletenosti privrednih kretanja, za kreatore ekonomskih i drugih politika to znači simultano suočavanje sa "pritiskom" na resurse usled porasta broja stanovnika, te smanjenom ponudom radne snage usled starenja populacije (Lutz et al, 2008b, 3). Istovremeno, pomenute demografske promene 
mogu imati ključnu ulogu i u objašnjenju razlika u ostvarenim stopama rasta između zemalja (Kelley \& Schmidt, 2005, 279).

Zbog svega navedenog, za našu analizu postaje bitno razumevanje demografske tranzicije kao ključne snage koja je rukovodila evoluiranjem klasične Maltuzijanske populacione dinamike (vođene fiksnim faktorima proizvodnje) ka "režimu" održivog rasta (Galor \& Weil, 2000, 808). Nesinhronizovane pojave koje karakterišu istu su: smanjivanje mortaliteta, povećanje očekivanog životnog veka i dramatičan pad fertiliteta. Obim, brzina i vreme ovih promena nisu isti, te je prolazak kroz faze demografskih promena (dinamika odvijanja demografske tranzicije) različit po regionima i unutar njih.

Naime, neke zemlje još uvek nisu iskusile sve osobenosti demografske tranzicije (zemlje sa visokim stopama fertiliteta, kao i one sa 60 i više procenata stanovništva mlađeg od 30 godina), druge se nalaze u njenoj središnjoj fazi (kad $45-60 \%$ stanovništva pripada grupaciji mlađih od trideset godina), a postoje i privrede koje karakteriše tzv. postdemografska tranzicija - $\mathrm{u}$ njima su prisutne niske stope fertiliteta, demografska tranzicija se skoro okončala i dala za rezultat dominaciju starije populacije - manje od $45 \%$ populacije uzrasta ispod 30 godina i do jedne četvrtine stanovništva starijeg od 60 godina (Lehr, 2007, 1-26; Poot, 2008, 130-137; Leahy Madsen et al, 2010).

Generalno posmatrano, $u$ zemljama $u$ razvoju je još uvek prisutan značajan porast populacije. Tako, na primer, Afričke zemlje i dalje ostvaruju visoke stope rasta stanovništva, Latinska Amerika odnedavno ispoljava dramatičan pad stope fertiliteta, a negde između ova dva ekstrema se nalaze Srednji Istok i Južna Azija (Attanasio et al, 2006, 2). Iako sam rast populacije produkuje negativan efekat na rast per capita dohotka, to se može neutralisati statistički značajnim pozitivnim efektom koji nastaje usled rasta udela stanovništva koje je ekonomski aktivno. Drugim rečima, demografska tranzicija ovde ispoljava mehanički efekat na ponudu rada: stasavaju generacije onih koji su sposobni i voljni da rade, što $u$ okolnostima kad je tržište rada "spremno" da apsorbuje njihov priliv (ukoliko postoje valjano koncipirane politike i odgovarajuće institucionalno okruženje) može povoljno uticati na povećanje produktivnosti i dohotka.
Tako su demografske promene na ovom području $\mathrm{u}$ poslednje tri decenije dvadesetog veka generisale akceleraciju per capita dohotka za $0,7-1,35 \%$ godišnje (Bloom et al, 2001; Attanasio et al, 2006). Ovakav rezultat je skroman, ako imamo na umu da je reč o zemljama sa niskim dohotkom, ali je (u izvesnoj meri) obećavajući sa stanovišta činjenice da demografska tranzicija " $u$ povoju" generiše i objašnjava nešto ispod jedne trećine rasta nerazvijenih zemalja, te da će i u narednih pet decenija rast per capita dohotka (u proseku) biti 0,8\% (Attanasio et al, 2006, 20-21), što znači da je "prozor" za šanse još uvek otvoren.

Pošto su tržišta kapitala povezana i integrisana, potencijalni efekti demografske tranzicije na zemlje u razvoju, u velikoj meri, zavise od demografskih trendova u razvijenim zemljama i faktorske mobilnosti (Attanasio et al, 2006, 3). Ako nesinhronizovane demografske promene podstaknu kretanje kapitala ka nerazvijenim zemljama, njihov output će brže rasti.

Ključni makroekonomski efekti potpune demografske tranzicije na ovom području bili bi sledeći: značajan porast stope štednje, godišnji porast nadnica za oko $0,4 \% \mathrm{u}$ narednih pedeset godina, znatno smanjenje kamatnih stopa i, što je za našu analizu najznačajnije - porast prosečne produktivnosti 1,5 put tokom istog perioda usled promena starosne strukture aktivnog stanovništva indukovane tranzicijom $\mathrm{u}$ domenu fertiliteta (Attanasio et al, 2006, 19).

Kad je reč o razvijenim zemljama, demografska tranzicija je imala važnu ulogu u pojavi modernog rasta, jer je omogućila privredama da konvertuju veliki deo dobitaka od akumulacije kapitala i tehnološkog progresa u rast per capita dohotka (Galor \& Weil, 1999, 151; Galor, 2010, 1).

Fundamentalni preduslov da bi se iskoristila prilika koju nude demografske okolnosti bile su adekvatne i pravovremene odluke iz domena ekonomske politike. Nekolicina varijabli je uticala na sposobnost nekih država da to i ostvare. U pomenute spadaju: zdravstvena politika, planiranje porodice, politika obrazovanja i mere ekonomske politike koje unapređuju fleksibilnost tržišta rada, otvorenost za razmenu i promovišu štednju. Sve one su imale (i još uvek imaju) direktan i indirektan ("kolateralan" - Bloom et al, 2001) uticaj 
na brzinu odvijanja demografske tranzicije, ekonomski rast i razvoj.

Upravo su zemlje koje su 60-ih i 70-ih godina prošlog veka iskusile efekte ubrzane demografske tranzicije ostvarile značajan ekonomski rast, a ovaj fenomen su ekonomisti nazvali "demografska dividenda". Tako se, na primer, u slučaju Istočne Azije, trećina ostvarenih rezultata pripisuje iskorišćavanju povoljnih demografskih okolnosti (Bloom et al, 2000, 282).

Međutim, demografska dividenda nije neizbežna stvar, ona se mora "zaraditi". Otuda ne čude tvrdnje da je ovakav jednokratni (vremenski limitiran) "demografski poklon" (Golini \& Marini, 2005, 1) ekonomski svrsishodan ukoliko se "investira valjano u ljudski i fizički kapital i kreiraju prilike za zapošljavanje mladih" (World Bank, 2003, 36).

Naime, ukoliko porast populacije $\mathrm{u}$ radnom dobu nije praćen prilikama za njihovo upošljavanje, za rezutat imamo rastuću nezaposlenost. Zbog toga je naglašavanje značaja valjano osmišljenih i primenjenih politika važno, jer se kapitalizovanje "demografske dividende" ne dešava po nekakvom automatizmu. Drugim rečima, demografska tranzicija koja vodi ka "dominaciji" starosne grupe radno sposobnog stanovništva predstavlja šansu i priliku za jednu zemlju da takvu pogodnost eventualno i materijalizuje (u vidu veće produktivnosti i viših stopa rasta). To je učinio Japan "iskusivši" tzv. "populacioni bonus" - visoke stope rasta zahvaljujući povećanom udelu populacije u radnom dobu (Shirakawa, 2011).

Ipak, čini se da je demografski bonus iz dvadesetog veka (bar kad je reč o razvijenim privredama) stvar prošlosti (Coleman, 2006). Konkretno, prema prognozama (UN, 2011) do sredine ovog veka razvijene zemlje će iskusiti porast populacije starije od 60 godina za više od $50 \%$ (rast od 2,4\% godišnje). Broj starijh je u ovim oblastima već prevazišao broj dece (osoba ispod 15 godina), a njihov udeo u ukupnoj populaciji će od trenutih $22 \%$ dostići $32 \%$ do 2050. godine. Udeo populacije $\mathrm{u}$ radnom dobu, kao važan faktor koji pokazuje potencijal za ekonomski rast, neznatno je padao u periodu 1950-1970, nakon toga u izvesnoj meri narastao do 2005. (kada je dostigao $63 \%$ ), a potom ponovo ispoljio tendenciju smanjivanja (prema očekivanim projekcijama za 2050. godinu, isti će iznositi 51,5\%). Drugim rečima, prosečna godišnja stopa promene $\mathrm{u}$ grupaciji razvijenih će $\mathrm{u}$ naredne četiri decenije biti negativna - 0,31\%, prevashodno usled ekstremno nepovoljnih tendencija na ovom planu u Evropi (koju očekuje godišnje smanjenje radne populacije od $0,61 \%$, usled čega će udeo ove grupe $u$ strukturi ukupnog stanovništva biti oko $50 \%$ ). Iako u literaturi iz oblasti demografije i ekonomije ne postoji konsenzus oko definicije populacionog bonusa (jedni tvrde da je reč o periodu kad je udeo stanovništva u radnom dobu iznad 65\%, a drugi smatraju da je jedino bitno da se ovaj udeo povećava), nesumnjivo je da bi se u ovoj situaciji istraživači iz različitih oblasti složili da su razvijene zemlje "na pragu" ili su uveliko zakoračile u doba populacionog "onusa" (kad postojeća struktura populacije predstavlja teret i kočnicu daljeg prosperiteta).

Razvijene zemlje se, $\mathrm{u}$ načelu, nalaze pri kraju njihove demografske tranzicije. To znači da se u nekima od njih (poput Italije, Španije, Japana, Koreje, Singapura, Tajvana) promene već ispoljavaju u vidu smanjenja raspoložive radne snage i ubrzanog starenja stanovništva, dok će se u drugima ispoljiti najkasnije za deset do dvadeset godina (Bloom et al, 2003; Lutz et al, 2008b). Ovaj fenomen nameće nove izazove u sferi raspodele (u smislu transferisanja dohotka aktivnih na tržištu rada ka onima koji to nisu), vodi ka nižem rastu produktivnosti, manjoj fleksibilnosti na tržištu rada, povećanim troškovima zdravstvenog osiguranja, nege i zdravstvene zaštite (Heller, 2003; Poot, 2008; Shirakawa, 2011).

Da bi ustanovili da li postoji obrazac po kojem izmene u broju i strukturi stanovništva utiču na ekonomski rast, Bloom i drugi (2011) su poredili demografska kretanja u periodu 1960-2005. sa onim projektovanim do sredine ovog veka (istražujući kakav je mogao biti ekonomski rast da su demografske promene bile kao što današnje projekcije tvrde). Njihov obračun je pokazao da bi u okolnostima koje predviđa demografski scenario za budući period, više od polovine zemalja "iskusilo" sporiji rast; a kad je reč o zemljama OECD-a, njima je prošlost u demografskom smislu donela samo i isključivo "dobro" (Bloom et al, 2011, 19). Drugim rečima, okončao se period kad su razvijene privrede imale visoke udele radno sposobnog stanovništva i dobru demografsku kompoziciju istog 
(na primer, dominantno učešće grupacije onih od 30 do 49 godina - Prskawetz, 2007), a njih nadalje isčekuju posve drugačiji demografski trendovi sa nepovoljnim ekonomskim posledicama.

Sva pomenuta izračunavanja se odnose na računovodstvene (obračunske) efekte i zanemaruju sledeće promene $u$ ponašanju koje mogu biti inicirane izmenama u starosnoj strukturi: a) usled povećanja očekivanog trajanja života, produžava se radni vek: tako je prosek godina za odlazak u penziju na nivou Evropske Unije u periodu 2001. - 2008. rastao sa 59,1 na 61,4 (Bloom et al, 2011, 10), a postoje i predlozi da se starosna granica za penzionisanje pomeri na 72-75 godina (Coleman, 2006, 27); ovo povećanje prosečnog starosnog doba za penzionisanje transferiše pojedince iz sfere "zavisnih" u ekonomski aktivne (čime menja i brojilac i imenilac racia zavisnosti), te onemogućava usporavanje ili smanjivanje dostignutog životnog standarda; b) povećan životni vek indukuje porast ušteda tokom radnog veka; c) povećana je participacija radne snage (veće učešće žena); d) menja se investiranje u ljudski kapital - ispostavlja se tačnom Bekerova prognoza (Becker \& Luis, 1973) da će roditelji imati manji broj bolje obrazovane dece, mada ostaje nejasno da li manja grupa produktivnijih (kroz povećanje prosečnog nivoa dohotka i reduciranje poreskog opterećenja) može da nadomesti veću grupu manje produktivnih članova društva); e) prisutno je nužno povećanje zaposlenosti starije populacije.

Imajući u vidu navedene mogućnosti za prilagođavanja, stiče se utisak da je zbirni efekat promene u starosnoj strukturi stanovništva $u$ razvijenim zemljama na produktivnost, konkurentnost i ekonomski rast teorijski neodređen (Poot, 2008; Bloom et al, 2011): obračunski posmatrano, on je negativan (Jones, 2005), ali bi mogao biti delimično kompenziran dejstvom bihejvioralnih faktora.

\section{UBLAŽAVANJE NEGATIVNIH POSLEDICA STAROSNO-STRUKTURNE TRANZICIJE U EVROPI: MOGUĆA (NE)DEMOGRAFSKA REŠENJA}

Početkom ovog veka analitičari su prognozirali da će se, usled dugotrajnog pada stope fertiliteta, u narednih
25 godina stanovništvo Evrope smanjiti za $6 \%$, te da će do polovine XXI veka udeo ovog regiona u svetskoj populaciji ispoljavati tendenciju konstantnog opadanja (UN, 2001). U Evropi danas živi 10,6\% svetskog stanovništva, a usled očekivanja da prosečna godišnja stopa rasta stanovništva $u$ narednih četrdesetak godina bude negativna $(-0,24 \%)$, prognozira se da će 2050. ovo područje naseljavati između 6,1 i 7,8\% svetske populacije (UN, 2011). Usled pada stope fertiliteta nastaviće se starenje populacije; na duži rok kad se stabilizuje stopa rađanja, kontinuirano smanjenje stope smrtnosti će postati jedini uzročnik starenja stanovništva (Coleman, 2006, 19).

Zabrinutost zbog starenja populacije inicirala je niz diskusija na ovu temu, a posebna pažnja je posvećena budućim trendovima racia "potencijalne podrške" (odnosu broja ljudi u nominalno aktivnom životnom dobu (uobičajeno je reč o onima od 15 do 64 godine) prema broju pripadnika starije populacije (onih preko 65 godina života). U većini evropskih zemalja pomenuti racio je početkom ovog veka iznosio blizu 4, a prema očekivanjima i prognozama sredinom XXI veka isti će na nivou Evrope biti oko 2, a u Južnoj Evropi 1,4 (UN, 2011).

U ovoj deceniji će i broj ljudi u najproduktivnijim godinama za rad dostići svoj vrh, da bi zatim usledio pad. Takođe, za razliku od sredine prošlog veka kada je udeo mlade populacije $\mathrm{u}$ evropskim zemljama iznosio 27 , a onih starijih od 60 godina $12 \%$, sredinom ovog veka se očekuje dramatična promena ovih udela na 16 i 33\%, respektivno, a prosečna starost Evropljana će porasti sa 38 godina u 2000. na 49 godina u 2050 . godini (UN, 2011).

Evropske zemlje se, dakle, suočavaju sa problemom da se sve veći broj pripadnika starije populacije oslanja na reduciran broj onih u radnom dobu. U posebno teškoj situaciji se nalaze regioni Istočne i Južne Evrope koji će u uslovima niskog fertiliteta i zamašne emigracije pretrpeti rapidno smanjenje populacije (i apsolutno i relativno), što će prepoloviti broj stanovnika tokom ovog veka (Lutz et al, 2008b, 8).

Ovakvi trendovi su, sami po sebi, veoma problematični, a pogotovo ukoliko imamo u vidu činjenicu da su neke od zemalja sa ovog područja propustile priliku da iskoriste svoja pređašnja, unekoliko atipična, 
demografska kretanja. Naime, u poređenju sa ostalim delovima sveta, sredinom prošlog veka, ovaj region je imao visok udeo stanovništva u radnom dobu, ali nije uspeo da se time ekonomski "okoristi" (Bloom et al, 2003, 67). Takođe, udeo starije populacije u Istočnoj Evropi bio je manji (samo 12,9\%) u odnosu na ostale regione Evrope, a pored Srbije i Albanije, pred kraj prošlog veka procenat starije populacije $\mathrm{u}$ Rusiji je bio najniži u Evropi (Coleman, 2006, 9). To je, očito, bilo vreme kad je na putanji demografske tranzicije za nekolicinu zemalja još uvek bio "otvoren prozor" (Golini \& Marini, 2005, 3). Do sredine ovog veka udeo starije populacije u Istočnoj Evropi će porasti na $26 \%$, a Južna Evropa će imati čak 33\% populacije starije od 65 godina (Coleman, 2006, 19). Tada će se dodatno iskomplikovati poteškoće na planu efikasnosti i konkurentnosti usled pomenutog starenja, ali i kao posledica smanjenja stanovništva $\mathrm{u}$ radnom dobu (pogotovo onog mlađeg dela).

Imajući na umu nepovoljnost aktuelne demografske situacije, sasvim je logično preispitati kakve su mogućnosti da se njihovi (sasvim izvesno negativni) impulsi po ekonomski rast ublaže. Grubo uzevši, rešenja se mogu podeliti na demografska i nedemografska (Coleman, 2006).

Izbor demografskih solucija je skučen - da bi se povećao racio potencijalne podrške neophodni su povećanje fertiliteta i "pojačane" migracije. Konkretno, u svrhu pukog održanja postojećeg nivoa pomenutog racia, stopa ukupnog fertiliteta u Evropi bi morala da poraste na 3,5, a to je nemoguća "misija". Može li se migracijama mlađe populacije nadomestiti deficit stanovništva kreiran niskim stopama rađanja?

Iako su opšte koristi od migracije kvalifikovane radne snage nesumnjive, čini se da efekti ovakvih imigracionih kretanja nisu zamašni - na primer, ukoliko se želi očuvati postojeći racio potencijalne podrške, prosečno 25 miliona ljudi godišnje bi moralo da migrira u Evropu (Coleman, 2006, 22). Zbog toga je pomisao da bi to predstavljalo neku vrstu ekonomskog "spasa" za Evropu u potpunosti odbačena (Coleman \& Rowthorn, 2004, 609). Pored toga, u nekim delovima Jugoistočne Evrope situacija je komplikovanija, jer je ekonomska razvijenost ovih zemalja na daleko nižem nivou, te se ne smatraju atraktivnim područjem za imigraciju.
Pošto se čini da ne postoje demografske solucije za starenje stanovništva, neophodno je pribegavanje nedemografskim odgovorima (rešenjima) koja se odnose na poboljšanja $u$ obrazovnoj sferi, prilagođavanja na tržištu rada, u penzionom sistemu i pomeranja starosne granice penzionisanja.

Povećano ulaganje $\mathrm{u}$ obrazovanje populacije koja se nalazi u radnom dobu predstavlja značajnu determinantu sa isključivo pozitivnim dejstvom na ekonomski rast (Lutz et al, 2008a). Pod pretpostavkom da se ostvari "scenario" globalne edukacije, odnosno da budući trendovi upisa (tranzicije ka kategorijama višeg nivoa obrazovanja) $u$ svakoj zemlji slede sveukupnu trajektoriju istorijskih globalnih trendova (Lutz et al, 2008b, 15), obrazovni profil radne snage će se nesumnjivo konstantno poboljšavati.

Ako inputi rada nastave da opadaju usled tehnoloških promena, ova kombinacija malobrojnijih, ali bolje obrazovanih radnika može stimulativno delovati na povećanje produktivnosti rada - a to je upravo ono što je evropskim zemljama potrebno (Lutz et al, 2008b, 22). Ipak, neizvesno je da li će pozitivne posledice većih obrazovnih dostignuća moći da kompenziraju one negativne nastale (pomenutim) smanjenjem radne snage.

Pored toga, manje razvijene evropske zemlje se generalno suočavaju sa problemima nereformisanih tržišta rada i penzionih sistema, a po pravilu one zemlje koje su sa demografskog stanovišta u najlošijoj poziciji istovremeno imaju i najveće institucionalne poteškoće (Jackson \& Howe, 2003). Dakle, pošto se starenje populacije ne tretira samo kao demografski problem per se (Bloom et al, 2011, 29), već sve više kao funkcija rigidnih ili zastarelih institucija i politika, smatra se da je neophodna kombinacija "odgovora" za valjano upravljanje ovim promenama. To bi moglo da podrazumeva sledeće poteze (Coleman, 2006, 25-28):

- poboljšanje racia "realne" podrške, tj. povećanje udela aktuelne radne snage (putem povećanja učešća žena u radnoj snazi, skraćivanjem ciklusa trajanja studiranja, ranijim zapošljavanjem);

- modifikovanje obaveznog i dalji razvoj dobrovoljnog penzijskog osiguranja; 
- stimulisanje kapitalnih investicija u svrhu poboljšanja produktivnosti (a time i konkurentnosti i ekonomskog rasta); zahtevani rast produktivnosti da bi se "pokrio" problem koji nastaje starenjem stanovništva (porastom "zavisne" populacije) morao bi da bude bar $0,5 \%$ godišnje do 2020 . godine.

\section{DEMO-EKONOMSKA TRANZICIJA SRBIJE}

Kakvi su trendovi u kretanju populacije u Srbiji? Da li isti predstavljaju odraz tendencija ispoljenih $u$ regionu Jugoistočne Evrope? Da li se situacija pogoršala počev od poslednje decenije prošlog veka, s obzirom da opšte ekonomske prilike nisu bile pogodne za demografsku i demo-ekonomsku evoluciju?

S obzirom da su demografski indikatori Srbije prilično kontradiktorni, čini se da u njenom slučaju važi ista argumentacija kao i kod regiona Jugoistočne Evrope. $S$ jedne strane, naime, neki parametri iz poslednje decenije prošlog veka nagoveštavaju da je bilo prostora da se iskoriste relativno povoljne demografske prilike tog vremena. Tako je, na primer, udeo radno sposobnog u ukupnom stanovništvu iznosio $67,2 \%$, a udeo starije populacije tek 9,6\% (United Nations, 2011). Takođe, kada smo na osnovu podataka UN izračunali udeo najproduktivnije grupacije u ukupnom, te radno sposobnom stanovništvu $\mathrm{i}$ te veličine uporedili sa istim indikatorima $\mathrm{u}$ drugim regionima Evrope, dobijeni rezultati su bili slični i relativno obećavajući. Naime, udeo stanovništva od 30-49 godina u ukupnoj populaciji u poslednjih deset godina prošlog veka iznosio je 27,5\% u Srbiji, dok je taj udeo u radno sposobnom stanovništvu bio $41 \%$, što su veličine koje korespondiraju onima ostvarenim u regionu Severne Evrope. Međutim, kad preračunamo neke druge indikatore, situacija izgleda krajnje nepovoljno - kao da demografskih prilika nije ni bilo. Tako je, na primer, udeo dece i mladih do 30 godina u ukupnoj populaciji u Srbiji iznosio $44,75 \%$, a stanovništva iznad 60 godina $15,33 \%$. Pošto je manje od $45 \%$ stanovništva uzrasta ispod 30 godina, a blizu četvrtina onih od 60 godina i više, to odražava tzv. zrelu, ali za ekonomski rast i razvoj nepovoljnu, starosnu strukturu.

Situacija u Srbiji je tim komplikovanija pošto poslednjih desetak godina XX veka predstavljaju oličenje simultanog odvijanja dva tipa tranzicije, za koje će se vremenom ispostaviti da nisu tekla nezavisno jedna od druge: ekonomske, koja je u to vreme otpočela, te demografske (koja je trajala decenijama pre toga).

Nivo stopa ukupnog fertiliteta od oko 2,1 koji obezbeđuje prosto obnavljanje stanovništva, kod nas je zabeležen još sredinom pedesetih godina prošlog veka, da bi se devedesetih spustio na 1,74 (UN, 2011), uz tendenciju daljeg smanjivanja sve do druge polovine ovog veka. Smanjenje stope fertiliteta je, između ostalog, posledica same ekonomske tranzicije, konkretno: dramatičnog smanjenja životnog standarda, povećanja siromaštva, veće nesigurnosti po pitanju radnog mesta i dohotka, iseljavanja mlade populacije i slično.

Takođe, iako demografska tranzicija na području Srbije ima karakteristike regionalne varijacije (diferenciranje područja nedovoljnog, naspram oblasti prekomernog, rasta stanovništva), u celini posmatranoSrbijaje suočena sa procesom depopulacije. Shodno prognozama, u grupaciji od 49 zemalja čije će stanovništvo biti malobrojnije sredinom veka za bar desetak procenata (a usled dugotrajnijeg pada fertiliteta ispod nivoa zamene) nalaze se Bosna i Hercegovina, Bugarska, Hrvatska, Srbija, Rusija, Rumunija (UN, 2011).

Promene $u$ starosnoj strukturi kreću se $u$ pravcu apsolutnog i relativnog smanjivanja udela mladih uz istovremeni porast udela starih generacija, počev od 2000. godine, što je odlika zemalja koje se nalaze $u$ post-demografskoj tranziciji (Lehr, 2007; Poot, 2008). Racio ukupne zavisnosti se povećava i očekuje se da se efekti starenja na ekonomsku i dalju demografsku evoluciju naročito manifestuju $u$ ovoj deceniji. Naime, $u$ kontingent populacije $\mathrm{u}$ radnom dobu (koja je osnovni izvor aktivne populacije) stasavaju malobrojnije generacije onih rođenih $\mathrm{u}$ doba ekonomske tranzicije, a problem se potencira opadanjem nihove participacije na tržištu rada (odnosno kasnijim ulaskom na isto) usled produžavanja perioda školovanja (koji je iznuđena reakcija na smanjene prilike za iznalaženje posla odmah po diplomiranju).

Otuda nije iznenađenje da racio potencijalne podrške koji je krajem prošlog veka bio na nivou 4,87 (što je iznad evropskog proseka), u narednih desetak godina rapidnije počinje da pada, da bi sredinom ovog veka dospeo na 2,43. Za razliku od visoko 
razvijenih zemalja Severne ili Zapadne Evrope, koje će zadržati na relativno stabilnom nivou udeo stanovništva uzrasta 30-49 godina u grupaciji radno sposobnih, u Srbiji će i ova veličina pretrpeti pad. Ako tome dodamo oko pola miliona ljudi koji su od 19952005. emigrirali iz zemlje (UN, 2011), situacija se čini daleko nepovoljnijom. Konkretno, migratorna kretanja (rapidnije iseljavanje stanovništva) su uzrokovala ne samo trenutno smanjenje broja stanovnika, već i dugoročne demografske posledice ( $u$ vidu gubitaka u potencijalnom, budućem potomstvu). Ista su, takođe, nametnula strukturne promene jer emigrira visokoobrazovana mlađa populacija, čime se produkuju negativne konsekvence po produktivnost rada, ekonomski rast i razvoj privrede.

Stoga su analizirane demografske solucije za rešenje problema produkovanih demo-ekonomskom evolucijom na ovim prostorima potpuno neprimenjive. Srbija ne može povećati racio potencijalne podrške zahvaljujući migracijama, jer ne predstavlja područje atraktivno za doseljavanje stanovništva. Mada samo stopa fertiliteta suštinski menja kompoziciju populacionih grupacija, ovo rešenje takođe nije od značaja za Srbiju, pošto se deficit stanovništva prouzrokovan niskim stopama rađanja ne može kompenzirati u okolnostima kad ta stopa postaje još niža.

Izmenjena struktura stanovništva nije više striktno demografski problem jer je doba ekonomske tranzicije (sa lošim ekonomskim prilikama i velikim propustima u oblasti upravljanja ljudskim resursima) samo pogoršalo, ionako nepovoljne, trendove i ostavilo traga $\mathrm{u}$ vidu poremećaja tokova demografske tranzicije. Budući da problem prevazilazi demografski opseg, nedemografske solucije za rešavanje istog su jedino što Srbija ima u ovom trenutku na raspolaganju.

\section{ZAKLJUČAK}

Proučavanje uticaja populacionih promena na ekonomski rast i razvoj postaje atraktivnije za istraživače ne samo zbog objektivne aktuelizacije ovog pitanja $u$ godinama i decenijama koje dolaze, već i usled potenciranog interesovanja koje ovim povodom iskazuju institucije koje presudno utiču na produbljivanje analiza u domenu konkurentnosti.
U narednih nekoliko decenija svet će se suočavati sa dva sasvim oprečna trenda: daljim porastom broja stanovnika i ubrzanim starenjem populacije. Visoke stope fertiliteta $\mathrm{u}$ grupaciji nerazvijenih zemalja produkuju negativne efekte na njihov per capita dohodak. S druge strane, rast udela radno sposobnog i ekonomski aktivnog stanovništva može produkovati povećanje produktivnosti rada i konsekventno omogućiti rast dohotka. Ipak, samo u jednostavnim ekonomskim modelima određeni vidovi ekonomske politike omogućavaju iskorišćavanje prednostiaktuelne starosne strukture nerazvijenih zemalja i sticanje demografske dividende. $U$ realnim okolnostima, kao što smo videli, efekti demografskih promena na ovom području nisu zamašni: očekuje se da će isti generisati rast per capita dohotka od 0,8\% godišnje, ali ne i akceleraciju takvih razmera koja bi donela suštinsku izmenu statusa nerazvijenih zemalja.

U slučaju razvijenih zemalja prisutna je tzv. starosnostrukturna tranzicija. Nijma je, naime, demografska tranzicija ostavila nasleđe $\mathrm{u}$ vidu sve starije populacije u XXI veku. Iako porast udela ovog (sa stanovišta privredeneproduktivnog) segmenta stanovništva može da produkuje izvesne negativne posledice i inhibira ekonomski rast, iste ne moraju biti pogubne, pod rigoroznom pretpostavkom da je izvodljivo i moguće izvršiti simultana bihejvioralna prilagođavanja u vidu produženja radnog veka, veće štednje i povećanog ulaganja u ljudski kapital.

U demografskom smislu Srbija deli sudbinu razvijenih evropskih zemalja po pitanjima opadanja fertiliteta i porasta udela starije populacije. Međutim, situacija je na ovom području komplikovanija usled poremećaja toka demografske tranzicije izazvanog ekonomskom tranzicijom. Srbiji je, kao i drugim evropskim zemljama, neophodno i preko potrebno ulaganje u ljudski kapital, ne bi li se obrazovnim usavršavanjem i dostignućima radnog kontingenta stanovništva povećala produktivnost rada i bar delimično kompenzirale negativne konsekvence pada broja stanovnika. Stoga bi predmet nekog narednog istraživanja mogla biti analiza mogućih nedemografskih rešenja koja su primerena osobenostima demografske tranzicije $u$ Srbiji, a u funkciji su ostvarivanja pozitivnih pomaka na planu održive konkurentnosti njene privrede. 


\section{ZAHVALNICA}

Ovaj rad je deo Projekta osnovnih istraživanja (broj 179065), koji finansira Ministarstvo nauke Republike Srbije.

\section{REFERENCE}

Attanasio, O., Kitao, S., \& Violante, G. L. (2006). Quantifying the Effects of the Demographic Transition in Developing Economies. Advances in Macroeconomics, 6(1), 1-44.

Becker, G. S., \& Lewis, H. G. (1973). On the interaction between the quantity and quality of children. Journal of Political Economy, 81(2), 279-288.

Bloom, D., Canning, D., \& Malaney, P. (2000). Population Dynamics and Economic Growth in Asia. Population and Development Review, Supplement to Volume 26, 257-290.

Bloom, D., Canning, D., \& Sevilla J. (2001). Economic Growth and the Demographic Transition. NBER Working Paper 8685. Retrieved January 30, 2012, from http://www.nber.org/ papers/w8685

Bloom, D., Canning, D., \& Sevilla J. (2003). The Demographic Dividend, A New Perspective on the Economic Consequences of Population Change. Pittsburgh: Population Matters, A Rand Program of Policy-Relevant Research Communication

Bloom, D., Canning, D., \& Fink, G. (2011). Implications of Population Aging For Economics Growth. Program on the Global Demography of Aging. PGDA Working Paper, 64. Retrieved January 30, 2012, from http://www.hsph.harvard. edu/pgda/working.htm

Coleman, D. A., \& Rowthorn, R. (2004). The economic effects of immigration into the United Kingdom. Population and Development Review, 30(4), 579-624.

Coleman, D. (2006). Europe's Demographic Future: Determinants, Dimensions and Challenges. Retrieved January 30, 2012, from http://www.spsw.ox.ac.uk/fileadmin/ documents/pdf/WP32_Europe_s_Demographic_Future.pdf

Ekonomski rečnik. (2006). Beograd: Ekonomski fakultet.

Heller, P. (2003). Who Will Pay? Coping with Aging Societies, Climate Change and Other Long-Term Fiscal Challenges. Washington: International Monetary Fund.

Galor, O., \& Weil, D. (1999). From Malthusian Stagnation to Modern Growth. American Economic Review, Papers and Proceedings, 89(2), 150-154.
Galor, O., \& Weil, D. (2000). Population, Technology and Growth: From Malthusian Stagnation to the Demographic Transition and Beyond. American Economic Review, 90(4), 806-828.

Galor, O. (2010). The Demographic Transition: Causes and Consequences. Retrieved January 30, 2012, from http://www. brown.edu/Departments/Economics/papers/2010/2010-12_ paper.pdf

Golini, A., \& Marini, C. (2005). Demographic changes as factor of national development and international competitiveness. Retrieved January 30, 2012, from http://iussp2005.princeton. edu/download.aspx?submissionID $=51063$

Jackson, R., \& Howe, N. (2003). The 2003 Aging Vulnerability Index. Washington, D.C: Center for Strategic and International Studies and Watson Wyatt Worldwide. Retrieved January 30, 2012, from http://csis.org/files/media/csis/pubs/aging_index. pdf

Jones, B. F. (2005). Age and great invention. NBER Working Paper 11359, Cambridge: National Bureau of Economic Research. Retrieved January 30, 2012, from http://www.nber. org/papers/w11359.pdf

Kelley, A. C., \& Schmidt, R. M. (2005). Evolution of recent economic-demographic modeling: a synthesis. Journal of Population Economics, 18(2), 275-300.

Leahy Madsen, E., Daumerie, B., \& Hardee, K. (2010). The effects of age structure on development, Policy and Issue Brief. Washington, DC: Population Action International. Retrieved January 30, 2012, from http://www.populationaction.org/ oldmedia/SOTC_PIB.pdf

Lehr, C. S. (2007). Evidence on Demographic Transition. Retrieved January 30, 2012, from http://www.people.vcu. edu/ cascotese/Publications/Demographic\%20Transition. pdf

Lutz, W., Sanderson, W., \& Scherbov, S. (2008a). The Coming Acceleration of Global Population Ageing. Nature, 451, 716719 .

Lutz, W., Sanderson, W., Scherbov, S., \& Samir, K.C. (2008b). Demographic and Human-Capital Trends in Eastern Europe and Sub-Saharian Africa. Washington, D.C: Migration Policy Institute.

Maddison, A. (1995). Monitoring the World Economy: 1820-1992. Paris: OECD Development Centre.

Poot, J. (2008). Demographic change and regional competitiveness. Journal of Foresight and Innovation Policy, 4(1/ 2), 129-145. 
Prskawetz, A., \& Lindh, T. (Eds.). (2007). The Relationship Between Demographic Change and Economic Growth in the EU, Research Report 32, Vienna Institute of Demography, Retrieved January 30, 2012, from http://www.oeaw.ac.at/vid/ download/FB32.pdf

Shirakawa, M. (2011). The Transition from High Growth to Stable Growth: Japan's Experience and Implications for Emerging Economies. Remarks at he Bank of Finland 200th Anniversary Conference, Retrieved January 30, 2012, from http://www.bis.org/review/r110510a.pdf
United Nations. (2001). World Population Prospects: The 2000 Revision. Retrieved January 30, 2012, from http://www. un.org/esa/population/publications/wpp2000/chapter5.pdf

United Nations. (2011). World Population Prospects: The 2010 Revision. Retrieved January 30, 2012, from http://esa.un.org/ unpd/wpp/Documentation/publications.htm

World Bank. (2003). World Development Indicators. Washington DC, Retrieved January 30, 2012, from http://www.worldbank. org/data/wdi2003/people.pdf

World Economic Forum. (2011). The Global Competitiveness Report 2011-2012. Retrieved December 2, 2011, from http:// reports.weforum.org/global-competitiveness-2011-2012/\#=

Primljeno 14. juna 2012, nakon revizije, prihvaćeno za publikovanje 9. jula 2012.

Slavica Manić je docent na Ekonomskom fakultetu Univerziteta u Beogradu, gde je i doktorirala. Oblasti njenog naučnog istraživanja su: ekonomska metodologija, ekonomska teorija, heterodoksni ekonomski pristupi, teorija i politika konkurentnosti.

Dragan Azdejković je asistent na Ekonomskom fakultetu Univerziteta u Beogradu, na kome je i doktirarao. Oblasti njegovog naučnog istraživanja su: teorija odlučivanja, teorija igara, ekonometrija i rasplinuti sistemi. 